Isyatul Luthfi

\title{
METODE DAKWAH HAMKA DALAM MEMILIH PEMIMPIN: Studi Penafsiran Surat Al-Mā'idah/5 ayat 51 dalam Tafsir Al-Azhar
}

\author{
'Isyatul Luthfi \\ Institut Agama Islam Negeri Langsa \\ Email: isyatullutfi97@gmail.com
}

\begin{abstract}
Abstrak
Kepemimpinan non-muslim di Indonesia masib menimbulkan pro dan kontra di kalangan agamawan dan pemerintah. Hal tersebut antara lain disebabkan oleb adanya pemahaman masyarakat terhadap teks-teks keagamaan seperti surat al-Mäidah/5 ayat 51 yang secara tekstual dipahami sebagai larangan memilib pemimpin non-muslim. Tulisan ini berupaya menganalisis penafsiran Hamka tentang ayat tersebut dengan pendekatan ilmu dakwah, tafsir, dan hermeneutika. Hamka menggunakan pendekatan adabi ijtimāi dalam penafsirannya, sehingga kaya dengan konteks sejarah. Metode dakwah yang digunakan Hamka dalam penafsiran adalah metode al-mau'ighah al-Hasanah. Hasil penafsiran Hamka pada surat al-Mä'idab/5 ayat 51 adalah berupa pelarangan menjadikan nonmuslim sebagai pemimpin. Hal tersebut didasarkan kepada lingkaran hermeneutika Hamka karena kedalaman bahasa Arab yang dimilikinya dan pengetabuan bidang sejarah yang luas. Sedangkan hermeneutika dialektis Hamka tidak terlepas dari penulisan Tafsir alAzhar yang dilakukannya di balik jeruji besi akibat tuduban yang harus diterimanya, karena keadaan politik. Indonesia yang tidak stabil, pada saat itu kekuasaan ada di tangan Partai Komunis Indonesia.
\end{abstract}

Kata Kunci: Metode Dakwah, Auliyä, Tafsir Al-Az̧ar

\section{A. Pendahuluan}

Pro dan kontra kepemimipinan non-muslim di Indonesia sering merujuk pada ayat yang secara tekstual mengindikasikan larangan menjadikan nonmuslim sebagai pemimpin, yaitu surat al-Mā'idah/5 ayat 51. Mayoritas mufassir memahami ayat tersebut sebagai bentuk larangan non-muslim untuk menjadi pemimpin. Hal ini kemudian menjadi pedoman dalam memilih pemimpin, karena agama menjadi penilaian utama. Sedangkan aspek kapasitas, kemampuan, komitmen serta tanggung jawab, menjadi penilaian kedua. Oleh karena itu, penting untuk membangun paradigma masyarakat terkait relasi dengan nonmuslim dalam pemerintahan. Tema ini diangkat karena melihat keadaan muslim Indonesia yang beradu argumen tentang surat al-Mā'idah/5 ayat 51. Oleh karena itu, penulis perlu menganalisis penafsiran ayat tersebut melalui Tafsir al-Azhar dengan pendekatan dakwah, hermeneutik dan tafsir. Pemilihan terhadap Tafsir al-Azhar adalah karena tafsir tersebut berbahasa Indonesia sehingga mudah dipahami dan ditulis oleh orang Indonesia yang memahami kehidupan muslim Indonesia.

Syaikh Ali Makhfudz, dalam kitabnya Hidayatul Mursyidin menuliskan definisi dakwah sebagai dorongan agar manusia berbuat kebaikan dan mengikuti petunjuk, menyeru berbuat kebaikan dan mencegah dari kemungkaran, sehingga 
manusia mendapat kebahagiaan di dunia dan akhirat (Saputra, 2011: 1). Islam adalah agama dakwah. Artinya agama yang selalu mendorong pemeluknya untuk senantiasa aktif melakukan kegiatan dakwah. Maju mundurnya umat Islam sangat bergantung dan berkaitan erat dengan kegiatan dakwah yang dilakukannya, karena itu Alquran menyebutkan kegiatan dakwah dengan Ahsanu al-Qaul. Dengan kata lain, bisa disimpulkan bahwa dakwah menepati posisi yang tinggi dan mulia dalam kemajuan umat Islam, tidak dapat dibayangkan apabila kegiatan dakwah mengalami kelumpuhan (Saputra, 2011: 240).

Kondisi dan situasi zaman seperti sekarang yang ditandai dengan lahirnya berbagai penemuan baru, hal itu telah membawa perubahan besar bagi kehidupan manusia. Umat Islam begitu antusiasnya menerima dampak yang ditimbulkan bagi kehidupan mereka bukanlah hal yang seharusnya diperhitungkan (Puteh dan Ilyas: 2013: 65). Dengan pesona itulah umat Islam semakin sibuk dengan fantasi dunianya, sibuk dengan segala aktivitas, dan dengan kesibukan itulah mereka lupa terhadap posisi dirinya sebagai hamba Allah Swt., yang mempunyai tanggung jawab dan amanah untuk mengabdi kepada-Nya (Ibidem: 67).

Mengamati kondisi zaman yang begitu kronis, pada kenyataannya umat Islam masih cenderung berpendapat, bahwa melaksanakan dakwah digolongkan kepada fardu kifayah sehingga tidak mustahil umat Islam akan bersikap apatis, tidak peduli terhadap keadaan yang terjadi, membiarkan segala bentuk kemungkaran, penyelewengan serta hal-hal lain yang bertentangan dengan hukum Islam (Ibidem: 68).

"Tafsir al-Azhar" merupakan karya momentum Hamka karena melalui tafsir ini Hamka mendemonstrasikan keluasan pengetahuannya di hampir semua disiplin ilmu yang tercakup oleh bidang ilmu-ilmu agama, serta pengetahuan non-keagamaan yang kaya dengan informasi (Ismatulloh, 2015: 158). Berdasarkan hasil penelitian Howard M. Federspiel terhadap kitab-kitab tafsir yang dihasilkan oleh para cendikiawan muslim Indonesia dalam bukunya KajianKajian Alquran di Indonesia, hanya tafsir Hamka yang membicarakan mengenai konteks sejarah dari ayat-ayat Alquran dan kaitannya dengan peristiwa-peristiwa kontemporer (Faiz, 2002: 8). Tulisan ini akan menganalisis penafsiran Hamka terhadap surat al-Mā'idah/5 ayat 51: Hai orang-orang yang beriman, janganlab kamu mengambil orang-orang Yabudi dan Nasrani menjadi 'auliyä'; Sebahagian mereka adalah 'auliya' bagi sebahagian yang lain. Barangsiapa di antara kamu mengambil mereka menjadi wali, maka sesunggubnya orang itu termasuk golongan mereka. Sesunggubnya Allah tidak memberi petunjuk kepada orang-orang yang zalim. Ayat tersebut diyakini oleh banyak mufassir sebagai dalil larangan memilih pemimpin non-muslim. Dalam menganalisis penafsiran Hamka tentang ayat tersebut diaplikasikan pendekatan ilmu dakwah, hermeneutik, dan tafsir. Ketiga metode tersebut digunakan untuk mencari tahu bagaimana strategi dan metode dakwah apa yang digunakan Hamka sehingga penafsirannya menjadi seruan kebaikan bagi umat muslim. Sedangkan hermeneutika diaplikasikan agar menghidupkan dan merekontruksikan penafsiran Hamka dalam jaringan interaksi antar pembaca, 
pendengar, dan kondisi batin serta sosial yang melingkupinya agar penafsiran tersebut tidak mengalami alienasi.

\section{B. Antara Dakwah, Tafsir dan Hermeneutika}

Ditinjau dari segi bahasa dakwah berarti panggilan, seruan atau ajakan. Kalimat tersebut adalah mashdar dari $d a^{\top} \bar{a}, y a d^{\prime} \bar{u}$, da'watan. Orang yang berdakwah disebut $d \bar{a} i c$ dan orang yang menerima dakwah disebut mad'ú. Secara istilah dakwah menurut Prof. Dr. Hamka adalah seruan panggilan untuk menganut suatu pendirian yang ada dasarnya berkonotasi positif dengan substansi terletak pada akitivitas yang memerintahkan amar makruf nabi mungkar (Saputra, 2011: 1).

Ilmu dakwah merupakan bagian dari ilmu-ilmu keislaman yang berakar pada tauhid. Di antara ilmu-ilmu lain yang dibangun berdasarkan pondasi tauhid, ilmu dakwah dapat dipikirkan sebagai ilmu yang memiliki posisi strategi karena ia berusaha mengaktualisasikan tauhid kedalam realitas kehidupan nyata. Ilmu dakwah dengan demikian dapat dikategorikan dalam dua. Pertama, ilmu dakwah teoretik: yaitu salah satu disiplin ilmu dakwah yang berusaha memberikan kerangka teori dan metodologi dakwah Islam. Kedua, ilmu Dakwah terapan (teknologi dakwah) yaitu salah satu ilmu dakwah yang berusaha memberikan kerangka teknis operasional kegiatan dakwah Islam (Ibidem: 124-125).

Ilmu dakwah adalah akumulasi pengetahuan yang dikembangkan umat Islam dalam susunan yang sistematis dan terorganisasi dalam membahas masalah yang timbul, dengan tujuan untuk memeperoleh pemahaman yang tepat mengenai kenyataan dakwah sehingga diharapkan dapat diperoleh susunan pengetahuan yang bermanfaat bagi penegakan tugas dakwah dan khalifah umat manusia. Fungsi keilmuan dakwah ada tiga. Pertama, memberi penjelasan tentang upaya mentranformasikan nila-nilai kebenaran dan memberikan penjelasan manhaj (kaifiyah) dalam mewujudkan ajaran Islam kedalam tatanan Khairu alUmmah. Kedua, memberi penjelasan tentang upaya transformasi iman ke dalam hati. Ketiga,memberi penjelasan tentang upaya membangun dan mengembalikan manusia pada fitrahnya, meluruskan tujuan hidup manusia menurut Alquran dan hadist (Ibidem: 124). Untuk mencapai ketiga hal tersebut dibutuhkan metode yang handal, dan Alquran telah menjabarkannya dalam surat al-Nahl/16 ayat 125: Serulah manusia kepada jalan Tuban-mu dengan bikmah, dan pelajaran yang baik dan bantablah mereka dengan cara yang baik. Sesunggubnya Tubanmu Dialah yang lebih mengetahui tentang siapa yang tersesat dari jalan-Nya dan Dialah yang lebih mengetahui orang-orang yang mendapat petunjuk. Dari uraian ayat tersebut dapat disimpulkan metode dakwah terdiri dari:

\section{Metode bi al-Hikmah}

Kata "hikmah" dalam Alquran disebutkan sebanyak 20 kali dalam bentuk nakirah maupun ma'rifah. Bentuk masdarnya adalah hukuman yang diartikan secara makna aslinya adalah mencegah. Jika dikaitkan dengan hukuman berarti mencegah dari kezaliman, dan jika dikaitkan dengan dakwah berarti menghindari hal-hal yang kurang relevan dalam melaksanakan tugas dakwah. Menurut Imam 'Abdullāh bin Ahmad Mahmūd al-Nasafī dakwah bi al-hikmah 
adalah dakwah dengan menggunakan perkataan yang benar dan pasti, yaitu dalil yang menjelaskan kebenaran dan menghilangkan keraguan. Metode dakwah ini menjelaskan doktrin-doktrin Islam serta realita yang ada dengan argumentasi yang logis dan bahasa yang komunikatif. Oleh karena itu metode ini merupakan sistem yang menyatukan antar teoritis dan praktis dalam berdakwah.

Dari penjelasan di atas dapat diambil kesimpulan bahwa hikmah dalam dunia dakwah mempunyai posisi yang sangat penting, yaitu dapat menentukan sukses tidaknya dakwah. Dalam menghadapi mad'ú yang beragam tingkat pendidikan, sastra sosial, dan latar belakang budaya, para dai memerlukan metode dakwah ini, sehingga ajaran Islam mampu memasuki ruang hati para mad' $\bar{u}$ dengan tepat (Ibidem: 247).

\section{Metode al-Mau'idzah al-Hasanah}

Secara bahasa al-mau'izhah al-hasanah terdiri dari dua kata, yaitu man'iz̧ dan hasanah. Kata mau'izhah berasal dari kata wa'adza-ya'idzu-wa'dzan-'idzatan yang berarti nasihat, bimbingan, pendidikan dan peringatan, sementara hasanah merupakan kebalikan sayyiah yang berarti kebaikan lawan kejelekan. Menurut Abdullah Hamid al-Bilali al-mau'ighah al-hasanah merupakan salah satu manhaj (metode) dalam dakwah untuk mengajak ke jalan Allah dengan memberikan nasihat atau membimbing dengan lemah lembut agar mau berbuat baik. Alman'izhah al-hasanah dapat juga diartikan sebagai ungkapan yang mengandung unsur bimbingan, pendidikan, pengajaran, kisah-kisah, berita gembira, peringatan, pesan-pesan positif (wasiat) yang dapat dijadikan pelajaran (Ibidem: 252). Al-mau'izhah hasanah dalam bentuk bimbingan, pendidikan dan pengajaran dalam diartikan sebagai nasihat nabi kepada umatnya, guru kepada muridnya, kyai kepada santrinya, mursyid kepada pengikutnya, dan lain-lain.

Dari definisi di atas, al-mau'iz̧hah al-hasanah dapat diklasifikasikan dalam beberapa bentuk:

1. Nasihat atau petuah

2. Bimbimgan, pengajaran (pendidikan)

3. Kisah-kisah

4. Kabar gembira dan peringatan (al-Basyīr dan al-Nadzir)

5. Wasiat (pesan-pesan positif)

Menurut K. H. Mahfudz kata tersebut mengandung arti:

a. Didengar orang, lebih banyak lebih baik suara panggilannya.

b. Diturut orang, lebih banyak lebih baik maksud tujuannya sehinnga menjadi lebih besar kuantitas manusia yang kembali ke jalan Allah Swt.

\section{Metode al-Mujädalah}

Dari segi etimologi lafal jādalab terambil dari kata "jadala” yang bermakna memintal dan melilit. Apabila ditambah alif pada huruf jim denga wazan fä́ala dapat bermakna berdebat, dan mujädalah adalah bentuk mashdarnya. Kata jadalah dapat bermakna menarik tali dan mengikatnya guna menguatkan sesuatu. Orang yang berdebat bagaikan menarik dengan ucapan untuk meyakini lawannya 
dengan menguatkan pendapatnya melalui argumentasi yang disampaikan (Ibidem: 254).

Dari segi terminologi terdapat beberapa pengertian al-mujädalah. Almujädalah berarti upaya bertukar pendapat yang dilakukan oleh dua pihak secara sinergi, tanpa adanya suasana yang mengharuskan lahirnya permusuhan. Sedangkan menurut Dr. Sayyid Tantawi ialah suatu upaya yang bertujuan untuk mengalahkan pendapat lawan dengan cara menyajikan argumentasi dan bukti yang kuat (Ibidem).

Dari pengertian di atas dapatlah diambil kesimpulan bahwa al-mujädalah merupakan tukar pendapat yang dilakukan oleh dua orang pihak secara sinergis, yang tidak melahirkan permusuhan dengan tujaun agar lawan dapat menerima pendapat yang diajukan dengan memberikan argumentasi dan bukti yang kuat Ibidem).

Tafsir secara bahasa berasal mengikuti wazan "taf' $l$ ", berasal dari kata fasara (fä, sin, rà) yang berarti menjelaskan, menyingkap, dan menampakkan makna yang abstrak. Kata al-tafsir dan fasara mempunyai arti menjelaskan dan menyingkapi yang tertutup. Dalam Lisān al-'Arab dinyatakan: "fasar" berarti menyingkapi sesuatu yang tertutup, sedangkan kata "al-tafsir" berarti menyingkapi sesuatu maksud lafaz yang musykil (Al-Qattan 2007: 456).

Tafsir menurut istilah, sebagian ulama berpendapat bahwa tafsir bukan ilmu yang sangat berbeda dengan ilmu-ilmu yang lain, karena tafsir bukanlah ilmu yang dibangun dari praktek dan kaidah-kaidah. Cukuplah memperjelas dan menjelaskan maksud kalam Allah Swt, itu sudah bagian dari tafsir (Zhahabī, 2012: 17). Abū Hayyan mendefinisikan tafsir sebagai: "Ilmu yang membahas tentang cara pengucapan lafaz-lafaz Alquran, tentang petunjuk-petunjuknya, hukum-hukumnya baik ketika berdiri sendiri maupun ketika tersusun dan makna-makna yang dimungkinkanbaginya ketika tersusun serta hal-hal yang melengkapinya." Kemudian Abū Hayyan menjelaskan secara rinci unsur-unsur definisi tersebut antara lain:

Kata-kata "ilmu" meliputi segala bentuk ilmu yang membahas cara mengucapan lafal-lafal Alquran, mengacu kepada ilmu qiraat. "Petunjuk-petunjuknya" adalah pengertian atau maksud yang dikehendaki lafaz, ini mengacu kepada ilmu bahasa yang diperlukan dalam ilmu tafsir. "Hukum-bukum" yang dimaksud meliputi ilmu saraf, ilmu irab, ilmu bayan dan ilmu badi: "Makna-makna" yang dimaksud meliputi pengertian yang hakiki dan majazi, sebab suatu kalimat terkadang membutubkan majaz. untuk melabirkan makna sebenarnya. "Hal-hal yang melengkapinya" meliputi pengetabuan nasakh, asbabu an-Nuzul, kisah-kisah yang dapat menjelaskan sesuatu yang kurang jelas dalam Alquran (Al-Qattan, 2007: 457).

Begitu banyak ilmu yang dibutuh dalam memahami Alquran sehingga ilmu tafsir hadir untuk menjawab hal tersebut agar memudahkan dalam memahami Alquran, dan agar tidak terjadi kesalahan dalam memahami Alquran.

Secara etimologis kata hermeneutika (hermeneutic) berasal dari bahasa Yunani dari kata kerja bermeneuin yang berarti menjelaskan, menerjemahkan, dan mengekspresikan. Kata bendanya hermeneia, artinya tafsiran. Dalam tradisi Yunani kuno kata hermeneuein dan hermeneia dipakai dalam tiga makna, yaitu 
(1) mengatakan, "to say" (2) menjelaskan "to explain" dan (3) menterjemahkan "to translate". Tiga makna inilah yang dalam bahasa Inggris diekspresikan dalam kata: to interpret. Interprestasi dengan demikian menunjukkan pada tiga hal pokok: pengucapan lisan (an oral ricitation), penjelasan yang masuk akal (a resonable explation), dan terjemahan dari bahasa lain (a reation from another language) (Sofyan, 2014).

Istilah hermeneutika diasosiasikan pada Dewa Hermes (Hermaies) dalam motologi Yunani yang bertugas menyampaikan pesan tuhan dari gunung Olympus kepada manusia. Konon ketika Hermes dihadapkan pada persoalan pelik ketika harus menyampaikan pesan Zeus untuk manusia. Yaitubagaimana menjelaskan bahasa Zeus yang menggunakan "bahasa langit" agar bisa dimengerti oleh manusia yang menggunakan "bahasa bumi". Akhirnya dengan segala kepintaran dan kebijaksanaannya, Hermes menafsirkan dan menterjemahkan bahasa Zeus ke dalam bahasa manusia sehingga menjelma menjadi sebuah teks suci. Katateks berasal dari bahasa Latin yang berarti produk tenunan ataupintalan. Dalam hal ini yang dipintal oleh Hermes adalah gagasan dankata-kata Zeus agar hasilnya menjadi sebuah narasi dalam bahasa manusia yang bisa dipahami (Ibidem).

Demikianlah, sejak awalnya hermeneutika telah berurusan dengan persoalan bagaimana menjelaskan bahasa, lisan maupuntulisan, yang tidak jelas, kabur, atau kontradiksi sehingga dengan amatmudah dimengerti dan tidak menimbulkan keraguan, kebimbangan dan salah tafsir bagi pendengar atau pembacanya. Kemudian dalam perkembangan selanjutnya, hermeneutika menjadi sebuahdisiplin filsafat yang memusatkan bidang kajiannya pada persoalan "understanding of understanding (pemahaman-pemahaman) terhadap sebuah teks, terutama teks kitab suci, yang datang dari kurun waktu,tempat, serta situasi sosial yang asing atau berbeda denganpembacanya (Ibidem).

Bila hermeneutika dikaitkan dengan "ilmu tafsir" maka dapat dipahami sebagai interpretasi atau pemahaman terhadap teks yang dibaca dan bagaimana satu teks dimunculkan oleh pengarangnya dan muatan apa yang masuk dan ingin dimasukkan oleh pengarang ke dalam teks yang dibuatnya, juga berusaha melahirkan kembali makna tersebut sesuai situasi dan kondisi saat teks tersebut dibuat (Faiz, 2002: 12).

Dalam teori Gadamer membaca dan memahami sebuah teks pada dasarnya melakukan dialog dan membangun sintesis antar dunia teks, dunia pengarang, dan dunia pembaca. Ketiga hal ini memiliki konteks tersendiri sehingga jika mengabaikan satu dari tiga, maka pemahaman teks menjadi kering dan miskin. Untuk mendapatkan pemahaman yang maksimal Gadamer mengajukan beberapa teori sebagai berikut:

Pertama, Prasangka Hermenutika, adalah membaca dan memahami teks dengan teliti dan kritis agar sebuah teks tidak menjajah kesadaran kognitif pembaca sebab sebuah teks yang tidak diteliti dan diintegrasi secara kritis tidak menutup kemungkinan besar sebuah teks akan menjajah kesadaran kognitif kita. Tetapi adalah hal yang tidak mudah bagi seseorang untuk memperoleh data yang 
akurat mengenai asal usul sebuah teks dan cenderung untuk menerima sumber otoritas tanpa argumentasi kritis (Sofyan, 2014).

Kedua, Lingkaran Hermeneutika atau Prasangka Hermeneutika ia sebenarnya hendak menekankan perlunya "mengerti". "Prasangka hermeneutik" bagi Gadamer nampaknya baru merupakan tangga awal untuk dapat memahami sebuah teks secara kritis. Bagi Gadamer mengerti merupakan proses yang melingkar. Maksudnya dalam mencapai suatu kepahaman terhadap teks diperlukannya pra-pemahaman terhadap teks tersebut. Jika tidak, maka tidak mungkin akan memperoleh pengertian tentang teks tersebut. Apa yang dimaksudkan dengan "prasangka hermeneutika" dan "lingkaran hermeneutika" bagi Gadamer di atas mengandaikan bahwa dalam melakukan interpretasi atau pemahaman terhadap suatu teks, seorang hermeneut atau pelaku interpretasi tidak berada dalam keadaan kosong. Dia akan membawa serangkaian praanggapan ke dalam teks tersebut. Bila teori ini kita kaitkan dengan ilmu tafsir dalam tradisi Islam, maka seorang mufassir Alquran, ia akan membawa sejumlah prasangka berupa pengetahuannyatentang bahasa Arab, puisi, konteks dan intra teks dalam Alquran. Dengan kata lain seorang mufassir pasti akan membawa sejumlah pemahaman sesuai teks sebelum menafsirkannya (Ibidem).

Ketiga, Aku-Engkau menjadi Kami, menurut Gadamer sebuah dialog seperti dialog "kita" dengan teks akan dipandang sebagai dialog yang prodiktif jika formulsi subjek-objek "aku-engkau" telah hilang diganti dengan "kami". Sebetulnya pemahaman itu tidak hanya sampai disitu, karena kesadaran subjek yang dari "aku-engkau" menjadi "kami" masih potensial untuk menghalangi sebuah partisipasi maksimal untuk memperoleh pemahaman yang benar sebelum subjek "kami" hilang melebur pada substansi yang didialogkan. Ibarat pemain bola, yang bisa diperoleh secara benar dan autentik ketika yang bersangkutan mengalami sendiri serta lebur di dalam peristiwa permainan yang sehat dan ideal di mana pemain, wasit, penonton meninggalkan indentitas "keakuannya" dan semuanya tertuju pada kualitas dan seni permainan itu sendiri. Jadi sikap memahami sebuah teks sedapat mungkin bagaikan upaya memahami dan menghayati sebuah festival yang menuntut apresiasi dan partisipasi sehingga pokok bahasan itu sendiri yang hadir pada kita, bukan lagi kesadaran subjek-objek (Ibidem).

Keempat, Hermeneutika dialektis, Gadamer menegaskan bahwa pemahaman kita senantiasa merupakan suatu yang bersifat historis, peristiwa dialektis dan peristiwa kebahasaan. Hermeneutika adalah ontologi dan fenomenologi pemahaman. Kunci bagi pemahaman adalah partisipasi dan keterbukaan. Lebih lanjut menurut Gadamer, hermeneutika berhubungan dengan pengalaman, bukan hanya pengetahuan. Hermeneutika dialektis membimbing untuk menyingkapi hakekat kebenaran, serta menemukan hakekat realita segala sesutu secara sebenarnya (Ibidem).

Dari uraian di atas secara etimologis nampaknya tidak ada perbedaan antara hermeneutika dengan penafsiran. Atau dengan ungkapan lain hermeneutika adalah merupakan seni berintrepretasi. Jika demikian bila dibandingkan dengan ilmu tafsir dalam tradisi keilmuan Islam, maka 
hermeneutika semakna dengan tafsir atau penafsiran. Meskipun dalam perjalanan sejarah keduanya dibedakan dalam tataran teologis. Penafsiran biasanya disejajarkan dengan praktik penafsiran, sedangkan hermeneutika menunjuk kepada tujuan, prinsip dan kriteria dari praktek tersebut. Dengan kata lain, hermeneutika adalah teori penafsiran (Ibidem).

Hermeneutika sebagai bentuk upaya penafsiran dan memberi makna atas sebuah teks, maka inti dari pemikiran hermeneutika Gadaamer bertumpu pada konsep "memahami". Pemahaman selalu dapat diterapkan pada keadaan kita saat ini, meskipun pemahaman itu berhubungan dengan peristiwa sejarah, dialetika dan bahasa. Oleh karenanya pemahaman selalu mempunyai posisi, misalnya posisi pribadi kita sendiri saat ini. Pemahaman tidak pernah bersifat objektif dan ilmiah. Sebab pemahamn bukanlah "mengetahui" secara statis dan di luar kerangka waktu, tetapi selalu dalam keadaan tertentu, pada satu tempat khusus dalam kerangka ruang dan waktu misalnya dalam sejarah. Semua pengalaman yang hidup itu mensejarah, bahasa dan juga pemahaman mensejarah. Proses pemahaman sebenarnya merupakan interpretasi itu sendiri. Sebab bila akal pikiran memahami maka di dalammya tercukup juga interpretasi. Sebaliknya bila akal pikiran kita melakukan interpretasi, maka terangkum juga pemahamannya (Ibidem).

Karena itu suatu peristiwa atau makna suatu teks yang nampak di hadapan kita bukanlah suatu yang tetap. Suatu kesadaran historis memuat hubungan antara masa lalu dan masa kini. Sedangkan masa kini telah kita ketahui melalui media universal yaitu bahasa. Dengan demikian cakupan pemahaman kita menjadi universal. Oleh karena itu hubungan manusia dengan dunianya pada hakekatnya adalah bersifat kebahasaan, oleh karena itu dapat ditangkap dan dipahami. Maka hermeneutika sebenarnya merupakan suatu yang universal dan bukannya hanya sekedar metode dalam memahami sesuatu (Ibidem).

\section{Tafsir Al-Azhar Karya Hamka}

Haji Abdul Malik Karim Amrullah atau lebih dikenal sebagai Hamka, lahir 16 Februari 1908 di Ranah Minangkabau, desa Kampung Molek, Nagari Sungai Batang, di tepian danau Maninjau, Luhak Agam, Sumatera Barat. Nama kecilnya adalah Abdul Malik, sedangkan Karim berasal dari nama ayahnya, Haji Abdul Karim dan Amrullah adalah nama dari kakeknya, Syeikh Muhammad Amrullah. Hamka seorang ulama multi dimensi, hal itu tercermin dari gelar-gelar kehormatan yang disandangnya. Dia bergelar "Datuk Indomo" yang dalam tradisi Minangkabau berarti pejabat pemelihara adat istiadat. Sebagai ulama Minang, Hamka digelari "Tuanku Syaikh", berarti ulama besar yang memiliki kewenangan keanggotaan di dalam rapat adat dengan jabatan Imam Khatib. Sebagai pejuang, Hamka memperoleh gelar kehormatan "Pangeran Wiroguno" dari Pemerintah RI. Sedangkan sebagai intelektual Islam, Hamka memperoleh penghargaan gelar "Ustadzyyah Fakhryyah" (Doctor Honoris Causa) dari Universitas Al-Azhar, Mesir, pada Maret 1959. Pada 1974 gelar serupa diperolehnya dari Universitas Kebangsaan Malaysia. Yaitu "Promovendus ProfessorDoctor 
Hamka”.'https://makalahnyafikri.files.wordpress.com/2012/08/biografi-fullhamka.pdf,diakses pada 20 Mei 2017)

Tafsir Al-Azhar berasal dari kuliah subuh yang diberikan Hamka di masjid Agung Al-Azhar sejak tahun 1959. Pada saat itu kondisi politik Indonesia sedang tidak stabil karena adanya agitasi dari kelompok PKI (Partai Komunis Indonesia) dalam mendiskreditkan orang-orang yang tidak sejalan dengan pandangan mereka. Masjid Agung Al-Azhar pun tidak luput dari serangan mereka (Faiz, 2002: 76). Masa ini dikenal dengan masa "Demokrasi Terpimpin" (1957-1966) yang tercatat dalam sejarah Indonesia sebagai masa penuh ketegangan khususnya antara presiden Soekarno, para pemimpin militer dan kelompok komunis, dalam menetapkan kembali UUD 1945 dan Pancasila sebagai falsafah negara selamanya, sehingga muncul perdebatan mengenai apakah Islam dapat dijadikan dasar negara atau tidak telah digugurkan (Faiz, 2002: 76-77). Sebagai anggota konstitante Masyumi Hamka menyampaikan pidato di Bandung pada tahun 1957 dalam hal menolak gagasan presiden Soekarno yang ingin menerapkan sistem Demokrasi Terpimpin. (https://makalahnyafikri.files.wordpress.com/2012/08/biografi-full-hamka.pdf, diakses pada 20 Mei 2017). Pada masa ini, ribuan aktivis politik ditangkap, dimana penangkapan ini merupakan strategi politik pemerintah yang pada saat itu dipegang oleh kelompok komunis untuk menendang para tokoh politik muslim yang dianggap mengancam keadaan mereka (Faiz, 2002: 77).

Hal yang sama juga dialami Hamka pada 27 Januari 1964, berlakulah takdir Allah yang oleh Hamka dikiaskan dengan kalimat, "Iika langit hendak jatuh, bagaimanalah telunjuk bisa menahannya." (https://makalahnyafikri.files.wordpress. com/2012/08/biografi-full-hamka.pdf, diakses pada 20 Mei 2017). Siang itu, usai memberikan pengajian mingguan di Masjid Agung Al-Azhar, Hamka dijemput empat orang polisi berpakaian preman, lengkap dengan surat perintah penahanan sementara. Di dalamnya disebutkan bahwa Hamka diduga melakukan kejahatan sesuai dengan PenPres No 11/1963. Tuduhan yang ditimpakan kepada Hamka adalah melakukan rapat-rapat gelap, menjadi anggota gerakan gelap untuk menentang Presiden Soekarno dan pemerintah Republik Indonesia yang sah. (https://makalahnyafikri.files.wordpress.com/2012/08/biografi-full-hamka .pdf, diakses pada 20 Mei 2017). Sebagai tahanan politik Hamka ditempatkan dibeberapa rumah peristirahatan di kawasan puncak, yakni di Bungalow HerlinaHarjuna, Bungalow Brimob Mamendung dan kamar tahan polisi Cimacan. (Faiz, 2002: 78).

Selama dua tahun lebih dalam tahanan, Hamka yang terkucil dari dunia ramai justru merasakan kedekatan yang demikian intim dengan Sang Khalik. Seluruh waktunya tercurah untuk menjalankan ibadah, mendekatkan diri kepada sumber dari segala sumber kehidupan. Dalam suasana yang demikian transendental, Hamka melanjutkan penafsiran Alquran hingga berhasil menyusunnya menjadi sebuah kitab lengkap 30 juz Tafsir Al-Azhar. (https://makalahnyafikri.files.wordpress.com/2012/08/biografi-full-hamka. pdf, diakses pada 20 Mei 2017). 
Tafsir Al-Azhar merupakan karya Hamka yang paling bersejarah. Salah satu niat Hamka menuliskan tafsir ini adalah ingin meninggalkan pusaka yang bermanfaat bagi bangsa dan muslim Indonesia jika kelak ia kembali ke hadirat Allah Swt. Penulisan Tafsir al-Azhar di mulai sejak tahun 1958, yang berbentuk uraian dalam kuliah subuh bagi jamaah masjid Agung Al-Azhar (Umar, 2015: 22).

Karakter umum dari Tafsir Al-Azhar adalah berbahasa non-arab, dalam penafsiranya Hamka senantiasa merujuk pada Tafsir al-Manar dan Tafsir Fi Zhiläl al-Qur'ān dan bercorak adab ijtimā'r. Secara umum metode yang digunakan Hamka dalam penafsiran adalah tabliti (analitis) hal tersebut tergambar dari penafsiran yang mengikuti sistem Alquran sebagaimana yang terdapat dalam mushaf Ustamani, dan bentuk Tafsir Al-Azhar lebih dominan menggunakan penalaran (bi al-ra'yi).

\section{Dakwah Hamka "Memilih Pemimpin” dalam Tafsir Al-Azhar}

Seruan pertama ayat tersebut adalah "amanü" bukan "al-Näss", ini menandakan bahwa orang yang mengaku dirinya beriman kepada Allah Swt, jangan menyerahkan kepemimipinan kepada "Yahudi dan Nasrani". Hal yang penting dalam ayat ini adalah disebutkan nama golongan mereka yaitu Yahudi dan Nasrani bukan nama kehormatan mereka, yaitu "Ahlulkitab". Ahli-ahli tafsir yang mendalami balaghah Alquran mengatakan bahwa dalam ayat ini tidak pantas disebut "janganlah kamu mengambil Ahlulkitab sebagai pemimpin”, karena kitab-kitab yang mereka terima dahulu tidak ada pembelajaran yang memusuhi tauhid yang nabi Muhammad Swa, dan kitab-kitab terdahulu tidaklah berlawanan dengan Alquran. Tetapi setelah mereka menamai mereka "Yahudi dan Nasrani" maka "Islam" telah ditingalkan, dan pendirian mereka pilih telah salah (Hamka, 2007: 274).

"Sebagian mereka adalah pemimpin bagi sebagian yang lain". Maksud ayat ini dalam dan jauh. Artinya jika Yahudi dan Nasrani diangkat menjadi pemimpin walau pun hanya sebagian kecil, ingatlah mereka akan memanggil teman mereka yang lain dengan tujuan bersatu dalam menghancurkan Islam, sehingga mereka yang akan memegang kepemimpinan. Sebagaimana yang terjadi di Bandung pada saat pemilihan anggota Badan Konstitusi. Wakil-wakil dari partai Islam ingin membentuk Undang-Undang Dasar yang terdiri dari tujuh kalimat "Dengan kewajiban menjalankan syariat Islam bagi pemeluknya”. Maka seluruh partai yang tidak setuju dengan ideologi tersebut sangat membenci Islam, bahkan dalam menghadapi Islam, Katolik, Protestan, partai-partai nasional, partai sosial dan partai komunis mereka saling bantu-membantu dan bersatu untuk menjatuhkan Islam. Pada tahun 1967, negeri Arab di serang oleh Yahudi selama empat hari dan Bait al-Maqdis dirampas dari tangan kaum muslim. Kemudian datang gagasan dari gereja Katholik agar Bait al-Maqdis diserahkan ke PBB, karena kekuasaan di PBB dipegang oleh negara Kristen (Perancis, Khatolik, Amerika Protestan, Inggris Anglicant dan Rusia (komunis). Di zaman Rasulullah kerja sama antara keduanya belum tampak karena Yahudi lebih dominan tinggal di Madinah dan Nasrani tinggal di Syam (Utara) dan Najran-Yaman (Selatan). 
Keajaiban Alquran terbukti, dalam perkembangan selanjutnya kedua agama yang bermusuhan itu dapat bersatu dalam memusuhi Islam. Sehingga berdiri negara Israel di tanah kaum muslim (Ibidem: 275).

"Barang siapa diantara kamu mengambil mereka menjadi pemimpin, maka sesunggubnya orang itu termasuk golongan mereka". Menurut Hamka kalimat ayat ini sangat penting untuk diperhatikan, yaitu: Barang siapa yang telah mengambil Yahudi dan Nasrani sebagai pemimpin, berarti termaksud golongan tersebut, artinya telah bersimpati kepada mereka. Tidak mungkin seseorang mengemukakan orang lain jadi pemimpin kalau dia tidak menyukai orang tersebut. Tapi, bukan berarti mereka telah pindah agama secara resmi. Menurut riwayat dari Abū Humaid Hudzaifah bin al-Yamanī berkata:

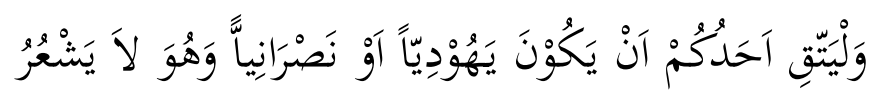

Hati-hatilah salah satu dari kalian akan menjadi Yabudi dan Nasrani, sedangkan dia tidak tan (Ibidem: 276).

Lihatlah bagaimana bangsa-bangsa Kristen menaklukkan negeri Islam, awalnya mereka mengajarkan bahasa mereka agar umat muslim berpikir dengan bahasa yang menjajah, sehingga umat muslim lemah dengan bahasa sendiri dan akhirnya terpengaruh oleh peradaban dan kebudayaan penjajah. Seiring waktu akan hilang kepribadian umat muslim, hilang landasan berfikirnya dan hilang perkembangan bahasanya. Lalu memandang tinggi kedudukan orang yang menajajah. Hal seperti ini telah kita rasakan ketika Belanda menjajah Indonesia (Ibidem: 276).

Menurut Hamka barang siapa yang mengangkat pemeluk agama lain jadi pemimpin berarti mereka telah beralih agama. Maksudnya agama Islam terkadang masih mereka kerjakan, tapi hakikatnya Islam telah hilang dari jiwa mereka. Karena ketertarikan yang luar biasa sehingga jiwa mereka tergadai kepada bangsa yang memimpin mereka, mereka tidak keberatan menjual agama dan bangsanya dengan harga murah. Ketika Belanda nyaris gagal menghadapi perlawanan rakyat Aceh mempertahankan kemerdekaan, didatangkanlah seorang jaksa beragama Islam dari luar Aceh untuk memetahkan perlawanan itu. Dia memberi masukan agar Belanda mendirikan tentara Marsose yang memakai bedil dan kelawang tapi, juga memakai rencong seperti orang Aceh untuk memusnahkan pahlawan muslim Aceh yang masih bertahan secara gerilya. Atas jasanya menunjukkan rahasia-rahasia umat seagama dia mendapatkan bintang Willemsorde dari Belanda. Konon jaksa tersebut adalah muslim yang taat shalat dan puasa (Ibidem: 277).

"Sesungguhnya Allah tidak memberi petunjuk kepada orang-orang yang zalim". Maksudnya orang yang telah mengambil Yahudi dan Nasrani menjadi pemimpin itu zhalim. Sebagaimana kita ketahui kata ₹halim berasal dari kata z̧bulm, artinya gelap. Mereka telah memilih jalan hidup yan gelap, sehingga terang telah dicabut Allah dari dalam jiwa mereka. Dalam surat al-Baqarah/2 ayat 120, Allah telah memperingati bahwa Yahudi dan Nasrani tidak rela selamanya sebelum umat Islam mengikuti agama mereka. Dalam ayat ini tegas dilarang mengambil mereka menjadi pemimpin. Hamka berpendapat dibolehkan memberi kepercayaan 
kepada pemeluk agama lain jika pemimpin tertinggi di tangan Islam. Karena tidak ada kekhawatiran. Tetapi jika menimbulkan kekhawatiran tidak boleh (Ibidem: 278-279).

Ada beberapa riwayat tentang turunnya ayat ini. Salah satunya yang diriwayatkan dalam hadis bahwa pendudukArab Madinah, dari suku Khazraj dan Aus sebelum mereka mememluk Islam telah membuat perjanjian saling membantu dengan suku-suku Yahudi yang ada di Madinah, yaitu bani Nadhir, bani Quraizah, bani Qainuqa'. Setelah mereka memeluk agama Islam dan nabi Muhammad Saw. hijrah ke Madinah, Nabi Muhammad Saw. membuat perjanjian-perjanjian dengan suku-suku Yahudi agar hidup damai, jika kota Madinah diserang mereka akan turut membantu. Dan keamanan mereka beragama dijamin oleh Rasulullah Saw. namun pada akhirnya mereka mengingkari janjinya, bahkan berkhianat.Yang pertama kali berkhianat adalah Yahudi dari bani Nadhir, ketika nabi datang ke kampung mereka untuk membayar diyat karena 'Amr bin Umayyah telah melakukan pembunuhan dengan kekhilafan ketika kembali dari sumur Ma'unah. Nabi disambut manis oleh mereka. Tetapi setelah nabi duduk bersandar pada satu dinding rumah, mereka berbisik akan menjatuhkan lesung bambu dari atas. Namun nabi mendapat ilham bahwa ada bahaya sehingga nabi langsung berdiri dan menghindar dari lesung tersebut, dan Nabi selamat (Ibidem: 279).

Setelah mengumpulkan bukti akhirnya penghianatan tersebut terbongkar, sehingga bani Nazhir dikepung dan mereka diperintahkan untuk menyerah. Tetapi Abdullah bin Ubay (kepala orang-orang munafik) menyuruh mereka tetap bertahan dan akan membantu mereka karena terikat janji lama. Namun setelah pengepungan besar-besaran terjadi tidak ada satu orang pun pengikut dari Abdullah bin Ubay ikut membantu, sehingga pengusiran terhadap bani Nadhir terus berlangsung (Ibidem).

Ada beberapa sahabat nabi yang memiliki keimanan dan rasa kesatria merasa kesulitan dengan janji saling membantu yang telah disepakati. Ada pula sahabat yang langsung menyatakan sikap yaitu, Sa'd bin Mu'adz. Karena penghianatan yang dilakukan bani Quraizhah ketika perang. Khandaq Sa'ad bin Mu'adz langsung menjatuhkan hukuman bahwa bani Quraizhah harus dihukum, semua laki-laki dibunuh, anak istrinya dijadikan tawanan dan harta benda dirampas. Padahal bani Quraizhah berharap Sa'd bin Mu'adz membela mereka karena ada janji saling membantu (Ibidem). Sikap yang sama ditunjukan pula oleh 'Ubadah bin Shamit. Melihat 'Abdullah bin Ubay secara munafik membela Yahudi, maka 'Ubadah bin Shamit menghadap nabi dan menyatakan sikap tegas, dan berkata dihadapan Nabi: "Ya Rasulullab! Ikatan janji kami dengan Yabudi dan agar saling membantu dan tolong-menolong. Aku tahu mereka memiliki sikap yang keras, banyak senjata dan kuat persatuannya. Tetapi, melibat keajadian ini, hari ini aku melepaskan diri dari perjanjian itu, dan langsung berlindung kepada Allah dan rasul-Nya. Tidak pimpinan melainkan pimpinan Allah dan Rasul!" Tetapi dalam keadaan yang sama 'Abdullah bin Ubay menyatakan bahwa dia tidak ada maksud untuk membatalkan janji tersebut. Namun pada akhirnya dia juga tidak sanggup memenuhi janjinya dengan Yahudi dari bani Nadhir untuk membantu mereka 
dan tidak pula bersiakp terang dengan Islam, sehingga dia dicap sebagai munafik (Ibidem: 280).

Namun yang dijadikan pedoman ialah isi kandung ayat, seperti dalam kaedah ushül al-fiqh:

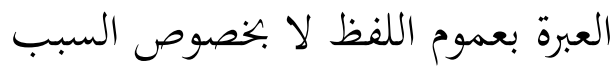

Yang dipandang adalah umum maksud perkataan, bukan sebab yang khusus

Artinya, yang dimaksud adalah maksud dan tujuan perkataan, bukan sebab turun ayat.

Bukankah sudah ratusan tahun lamanya negeri Islam menjadi jajahan Nasrani? Bagaimana hebatnya usaha mereka untuk menghilangkan pengaruh Islam? Kita sebagai negeri bekas jajahan pernah merasakan itu. Coba perhatikan kota Jakarta yang menjadi ibu kota republik Indonesia, adakah bukti bahwa di zaman penjajahan umat Islam boleh mendirikan masjid di tempat yang layak? Masjid hanya terdapat di belakang-belakang lorong dan di pingggir kota, sedangkan gereja berdiri di tempat-tempat penting dan megah. Hal ini karena kepemimpinan ada di tangan mereka (Ibidem).

Pada tahun 1920, seorang Demang (pegawai pemerintahan penjajahan Belanda, tetapi beragama Islam) bertanya tentang nusyuz kepada Adviseur Voor Inlansche Zaken yang dipimpin oleh orientalis yang sangat ahli dalam fiqih, yaitu Dr. Hazeu. Namun hukum yang ditetapkan sangat kaku, sehingga Dr. Syaikh Amrullah menyatakan banding atas hukum Dr. Hazeu dengan tegas. Padahal sebelum Dr. Hazeu, adveseur pemerintahan Belanda tentang Islam masih dipegang oleh seorang ulama yaitu Syaikh Usman al-Alawi (Ibidem: 281).

Dalam ayat ini tegas bahwa yang dilarang adalah mengambil mereka sebagi pemimpin. Tetapi hubungan pergaulan antar manusia tetap terjalin. Seperti hubungab umat Islam dengan dengan negara non-muslim dalam ekonomi, politik. Bahkan dalam surat al-Hujarāt/49 ayat 13, Allah menegaskan:

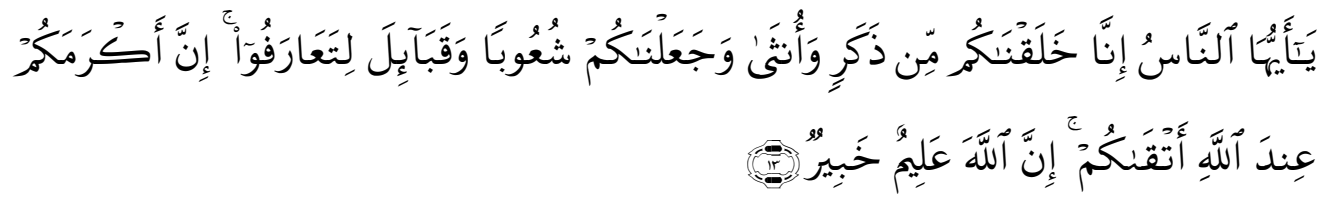

Hai manusia, sesunggubnya kami menciptakan kamu dari seorang laki-laki dan seorang perempuan dan menjadikan kamu berbangsa-bangsa dan bersuku-suku supaya kamu saling kenal-mengenal. Sesunggubnya orang yang paling mulia diantara kamu di sisi Allah ialah orang yang paling taqwa di antara kamu. Sesunggubnya Allab Maha mengetabui lagi Maba Mengenal (Ibidem: 278).

Ibnu Katsir dalam kitabnya Tafsir Ibnu Katsir, memiliki pemahaman yang sama dengan Hamka mengenai ayat ini. Menurut Ibnu kastir, Allah tabäraka wa ta'álā melarang hamba-hamba-Nya yang beriman mengangkat orang-orang Yahudi dan Nasrani sebagai pemimpin mereka, karena mereka adalah musuhmusuh Islam dan musuh para pemeluknya, semoga Allah membinasakan mereka. Selanjutnya Allah Ta'ala memberitahukan bahwa sebagian mereka adalah pemimpin bagi sebagian lainnya. Dan setelah itu Allah mengancam, dan menjanjikan siksaan bagi orang yang mengerjakan hal tersebut. Allah berfirman: 


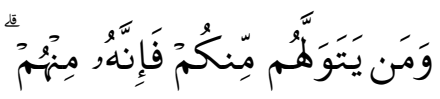

Barang siapa diantar kamu mengambil mereka sebagai pemimpin, maka sesunggubnya orang itu termaksud golongan mereka.

Riwayat Ibnu Abī Hātim mengatakan dari 'Iydh, bahwa 'Umar pernah menyuruh Abū Mūsā al-Asy'arī untuk melaporkan kepadanya pemasukan dan pengeluaran (yang dicatat) pada selembar kulit yang telah disamak. Pada waktu itu, Abū Mūsā al-Asy'arī mempunyai seorang sekretaris beragama Nasrani. Kemudian sekretarisnya menghadap 'Umar untuk memberikan laporan, maka Umar sangat kagum seraya berujar "Dia benar-benar orang yang sangat teliti, apakah kau bisa membacakan untuk kami di masjid satu surat yang baru kami terima Syam." Maka Abū Mūsā al-Asy'arī mengatakan bahwa dia tidak bisa. Maka 'Umar bertanya: “Apakah dia sedang berjunub?” Ia menjawab: “Tidak, dia seorang Nasrani," maka 'Umar pun menghardikku dan memukul pahaku, lalu berkata: “Keluarkan orang itu!’. Selanjutnya Umar membaca:

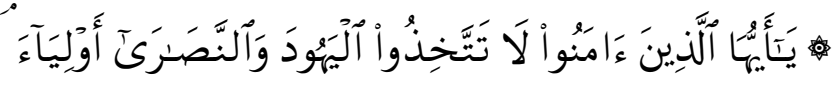

Hai orang-orang yang beriman, janganlah kamu mengambil orang-orang Yabudi dan Nasrani menjadi pemimpin-pemimpinmu (Ibnu Katsir, 2009: 106-107).

Dari penafsiran Hamka di atas dapat disimpulkan bahwa metode dakwah Hamka dalam Tafsir al-Azhar pada surat al-Mā’idah/5 ayat 51 adalah menggunakan metode dakwah al-Mauidzah al-Hasanah, karena dalam menafsirkan ayat tersebut Hamka senantiasa memberikan peringatan dan nasehat melalui sejarah atau kisah-kisah yang ditulis. Kisah-kisah tersebut menjadi peringatan sekaligus ajakan kepada umat muslim agar tidak memilih non-muslim sebagai pemimpin. Penyampaian Hamka juga sangat santun sehingga lebih mudah melahirkan kebaikan dan kepahaman terhadap alasan larangan memilih non-muslim sebagai pemimpin.

Dalam teori hermeneutika Gadamer ada empat hal yang harus dilakukan dalam memahami sebuah teks. Namun dalam hal ini penulis hanya menggunakan dua teori dalam menganalisis penafsiran Hamka yaitu "lingkaran Hermeneutika" dan "bermeneutika dialektis" sehingga hasil penafsiran Hamka pada surat al-Mā'idah/5 ayat 51 tidak mengalami aliensi.

Lingkaran hermeneutika disebut juga prasangka hermeneutika, artinya seorang yang melakukan interprestasi terhadap sebuah teks (ayat) pasti memiliki pra-pemahaman terhadap teks (ayat) tersebut. Jika melihat lingkaran hermeneutika yang dimiliki Hamka dalam menafsirkan surat al-Mā'idah/5 ayat 51. Pertama, pengetahuan Hamka tentang kedalaman bahasa Arab pada kalimat z.hulm kemudian mengkaitkan kalimat tersebut dengan surat al-Baqarah/2 ayat 120 . Kedua, konteks (asbāb al-Nuzül) ayat tersebut adalah tentang surat penghianatan Abdullah bin Ubay dikolerasikan dengan keadaan negeri-negeri Islam yang dikuasai oleh Nasrani dan Indonesia ketika dijajah. Ketiga, ilmu pengetahuan yang dimiliki Hamka dalam bidang sejarah menjadi lingkaran hermeneutika yang paling menonjol dalam menafsirkan ayat ini. 
Sedangkan hermeneutika dialektis yaitu, hermeneutika yang berhubungan dengan pengalaman, bukan hanya pengetahuan. Jika penafsiran Hamka dilihat dari hermeneutika dialektis hal ini berkaitan erat dengan pengalaman Hamka dalam menyelesaikan Tafsir al-Azhar. Hamka adalah seorang aktifis politik yang sangat aktif hal ini karena sebagai pejuang, Hamka memperoleh gelar kehormatan "Pangeran Wiroguno" dari pemerintah RI, Hamka juga sebagai anggota konstitante Masyumi pernah menyampaikan pidato di Bandung pada tahun 1957 dalam hal menolak gagasan presiden Soekarno yang ingin menerapkan sistem Demokrasi Terpimpin. Pengalaman politik yang dimiliki Hamka sangat mempengaruhi penafsirannya, sehingga penafsiran surat alMā’idah/5 ayat 51 sangat kental dengan sejarah Indonesia yang sedang dijajah. Tafsir Al-Azhar berasal dari kuliah subuh yang diberikan Hamka di masjid Agung Al-Azhar sejak tahun 1959. Pada saat itu kondisi politik Indonesia sedang tidak stabil karena adanya agitasi dari kelompok Partai Komunis Indonesia (PKI) dalam mendiskreditkan orang-orang yang tidak sejalan dengan pandangan mereka. Pada masa itu, ribuan aktivis politik ditangkap, dimana penangkapan ini merupakan strategi politik pemerintah yang pada saat itu dipegang oleh kelompok komunis untuk menendang para tokoh politik muslim yang dianggap mengancam keadaan mereka. Pada saat itu Hamka ikut ditangkap karena dituduh melakukan rapat gelap dan menjadi anggota gerakan gelap untuk menentang presiden Soekarno dan pemerintah republik Indonesia. Sehingga Hamka di penjara, dan pada saat di penjara Hamka menyelesaikan Tafsir AlAzhar sampai 30 juz.

Melihat pengalaman hidup Hamka yang diwarnai oleh persoalan politik yang pada saat itu Indonesia sedang dikuasai oleh PKI, hal ini sangat mempengaruhi penafsirannya terhadap surat al-Mā’idah/5 ayat 51 dalam menafsirkan kata auliy ä' sebagai pemimpin.

Namun, Secara umum auliy ä' adalah jamak dari wali makna dasarnya adalah "dekat". Dari makna dasar tersebut kemudian berkembang makna-makna baru. Dalam literatur bahasa Arab, auliyä' bisa bermakna teman dekat (al-shadiq), penolong (al-näshir), pengikut (al-täbi'), (al-mubibb) (Shihab, 2002: 123). "Wali" juga dapat diartikan pembantu (a'wan), yang dijadikan sandaran (zuburan) (alThabarī, 2001: 315). Semua makna tersebut diikat oleh benang merah berupa "kedekatan". Dalam kitab Kalimāt al-Qur'ān: Tafsìr wa al-Bayān, kata auliyä' pada surat al-Mā’idah/5 ayat 51 diartikan sebagai تؤاخونهم وتستتصرونه yang berarti berteman dengan mereka dan meminta pertolongan kepada mereka (Hasan, 1995: 65). Mayoritas mufassir memang memaknai lafaz tersebut dengan makna penolong, pelindung, teman dan sebagainya. Adapun pemaknaan lafaz auliy $\vec{a}$, yang mengarah kepada makna pemimipin sering kali dikembangkan oleh mufassir yang bergabung kelompok-kelompok revivalis yang mengandaikan terbentuknya negara Islam, di antaranya yaitu Sayyid Quthb dan Yusuf al-Qardhawi (Matswah, 2016: 26).

Selain kedua tokoh revivalis tersebut, lafaz auliy $\vec{a}$ ' dengan makna "pemimpin" juga terdapat dalam Tafsir Al-Azhar. Pemaknaaan tersebut dilatar belakangi oleh beberapa faktor, antar lain yaitu kondisi sosial politik ketika itu, 
seperti penjajahan bangsa asing (yang notabene non-muslim) terhadap bangsa Indonesia. Oleh karena itu, Hamka melihat gambaran kondisi masyarakat jika dipimpin oleh non-muslim. Faktor lainnya yaitu adanya misi kristenisasi di Indonesia yang banyak ditemui oleh Hamka diawal kemerdekaan. Faktor-faktor tersebut pada akhirnya mempengaruhi penafsiran Hamka terkait larangan menjadikan non-muslim pemimpin dan penguasa pemerintahan Indonesia (Ibidem).

\section{E. Simpulan}

Dalam menafsirkan surat al-Mā’idah/5 ayat 51, Hamka menggunakan pendekatan adab ijtimā' $\mathbf{\imath}$ sehingga penafsiran Hamka kaya dengan sejarah, hal ini menggambarkan metode dakwah dalam penafsiran Hamka adalah metode almau'izhah al-hasanah. Hal yang mempengaruhi lingkaran bermeneutika Hamka adalah pengetahuan Hamka dalam aspek bahasa Arab, pemahaman tentang asbāb al-nuzül dan pengetahuan yang luas mengenai sejarah. Dan yang mempengaruhi bermeneutika dialektis adalah ketika Hamka menyelesaikan Tafsir Al-Azhar keadaan politik Indonesia yang tidak stabil karena pemerintahan pada saat itu dikuasai oleh PKI (Partai Komunis Indonesia) yang mendiskreditkan orangorang yang tidak sejalan dengan pandangan mereka, sehingga Hamka ikut ditangkap dan dipenjara, dan hal ini dapat mempengaruhi penafsiran kata auliy $\vec{a}$, pada surat al-Mā'idah/5 ayat 51 sebagai “pemimpin”. Hasil penafsiran tersebut menggambarkan kekhawatiran Hamka yang timbul di masa itu jika non-muslim menjadi pemimpin. Melalui tafsirnya, Hamka mendakwahkan larangan menjadikan non-muslim sebagai pemimpin agar sejarah pahit tidak terulang.

Dalam hal ini penafsiran Hamka mengenai kata auliy $\vec{a}$ sebagai "pemimpin" rasanya kurang tepat jika dilihat dari hermeneutika dialektis Hamka, karena dalam kitab Kalimät al-Qur'ān: Tafsìr wa al-Bayān, auliyä’ pada surat alMā'idah/5 ayat 51 diartikan sebagai تؤاخونهم وتستتصرونه yang berarti "berteman dengan mereka" dan "meminta pertolongan kepada mereka". Ayat ini tidak secara langsung menegaskan arti pemimpin, karena konteks ayat tersebut berbicara tentang penghianatan yang dilakukan oleh 'Abdullah bin Ubay. 


\section{DAFTAR KEPUSTAKAAN}

A.M., Ismatulloh. Metode Dakwah dalam Alquran: Studi Penafsiran Hamka terhadap QS. an-Nabl. Jurnal Lentera, Vol. 11 No. 2, 2015.

Ap. Kau Sofyan. Hermeneutika Gadamer dan Relevansinya dengan Tafsir. Jurnal Farabi, Vol. 11 No. 1, 2014.

Faiz, Fakhruddin. Hermeneutika Qur'ani. Yogyakarta: Penerbit Qalam, 2002.

Hamka. Tafsir al-Az̧har. Singapura: Pustaka Nasional Pte.Ltd, 2007.

Kastir, Ibnu. Tafsir Ibnu Kastir. Jakarta: Pustaka Imam asy-Syafi'i, 2009.

Matswah, Akrima. Tafsir Kontekstual Terbadap Ayat Tentang Larangan Menjadikan Non-Muslim Sebagai Pemimpin (Studi Terbadap Surah al-Maidah [5]:51). Jurnal Suhuf, Vol. 9 No. 1, 2016.

Muhammad, Husain Makhlūf. Kalimät al-Qur'ān Tafsìr al-Bayān. Mesir: Hai'atu alIghatsah lil al-Islāmiyati al-'Alamiyah,1995.

Puteh Jakfar, Alwahidi Ilyas. Manajemen Dakwah Menurut Perspektif Alquran. Banda Aceh: Buku Laela, 2013.

al-Qattan, Manna Khalil. Mababis fi Ulumil Qur'an. Terj. Mudzakir AS. Studi IlmuIlmu Qur'an. Bogor: Pustaka Litera AntarNusa, 2007.

Saputra, Wahidin. Pengantar Ilmu Dakwah. Jakarta: Rajawali Pres, 2011.

Shihab, Muhammad Quraish. Tafsir al-Misbah: Pesan, Kesan dan Keserasian Alquran. Vol 3. Jakarta: Lentera Hati, 2002.

al-Thabarī, Abū Ja‘far Muhammad bin Jarìr. Jāmi' al-Bayān fì Tafsìr al-Qur'ān. Jilid 5. Kairo: at-Thaba'ah wa al-Nasyr wa al-Tauzi`‘ wa al-I'lān, 2001.

Umar, Ratna. Tafsir al-Azhar Karya Hamka: Metode dan Coraknya. Jurnal al-Asas, Vol. 3 No. 1, 2015.

Zhahabī, Muhammad Husain. Tafsìr wa al-Mufassirūn. Jilid I. Mesir: Darul Hadis, 2012.

Internet

(https://makalahnyafikri.files.wordpress.com/2012/08/biografi-full-hamka.pdf, diakses pada 20 Mei 2017) 